\title{
Atlantoaxial instability secondary to agenesis of the odontoid process of the axis without rupture of the dorsal atlantoaxial ligament in a dog
}

\author{
Instabilidade atlantoaxial secundária à agenesia do processo odontóide \\ do áxis sem ruptura do ligamento atlantoaxial dorsal em cão
}

\author{
Juliana Voll', Rodolfo Voll ${ }^{2}$, Leandro Gaiga ${ }^{1}$, João Antonio Tadeu Pigatto ${ }^{2}$ \& Fábio dos Santos Teixeira ${ }^{3}$
}

\begin{abstract}
Atlantoaxial instability is a congenital or traumatic or condition that causes cervical pain and varying degrees of neurological dysfunction. A case of atlantoaxial instability secondary to agenesis of the odontoid process of the axis without evidence of rupture of the dorsal atlantoaxial ligament in a dog treated sucessfully is presented. A nine-month-old male Lhasa Apso weighing $8.5 \mathrm{~kg}$ was referred to the Hospital de Clínicas Veterinárias (Veterinary Medical Teaching Hospital), Universidade Federal do Rio Grande do Sul (UFRGS), Porto Alegre/Brazil. The neurological examination revealed hyperesthesia to palpation of the cranial cervical region, tetraparesis not ambulatory with increased reflexes and proprioceptive deficiency in the thoracic and pelvic limbs. Radiographs of the cervical spine showed agenesis of the odontoid process of the axis without evidence of atlantoaxial instability. The diagnosis of atlantoaxial instability was based on the clinical signs and radiographic examination in the ventrodorsal view. Surgical stabilization was achieved with two Steinmann pins using ventral approach. One week after the surgery, neurological examination evidenced ambulatory tetraparesis and radiograph showed alignment of subluxation and the Steinman pins correctly positioned. In the present case, the clinical improvement was attributed to the joint stabilization and fibrous tissue formation around of the atlantoaxial joint.
\end{abstract}

Key words: Atlantoaxial instability, agenesis of the odontoid process of the axis, ventral approach, transarticular pins.

\section{RESUMO}

A instabilidade atlantoaxial é uma condição congênita ou traumática que causa dor cervical e vários graus de disfunção neurológica. Um caso de instabilidade atlantoaxial secundário a agenesia do processo odontóide do áxis sem evidência de ruptura do ligamento atlantoaxial dorsal em um cão tratado cirurgicamente com sucesso é relatado. Um cão da raça Lhasa Apso, macho, 9 meses de idade, 8,5 Kg atendido no Hospital de Clínicas Veterinárias da Universidade Federal do Rio Grande do Sul. O exame neurológico evidenciou hiperestesia à palpação da região cervical cranial, tetraparesia não ambulatória com reflexos aumentados e deficiência proprioceptiva nos membros torácicos e pélvicos. O exame radiográfico simples na posição ventrodorsal demonstrou agenesia do processo odontóide; não houve evidência de instabilidade atlantoaxial na posição látero lateral. $\mathrm{O}$ diagnóstico de instabilidade atlantoaxial secundária à agenesia de processo odontóide foi estabelecido pelos sinais clínicos e exame radiográfico na posição ventrodorsal. O cão foi submetido a tratamento cirúrgico utilizando-se a técnica de estabilização ventral com pinos transarticulares. A estabilização das vértebras foi feita com pinos de Steinmann e metilmetacrilato. Uma semana de pós-operatório o exame neurológico evidenciou tetraparesia ambulatória e o radiológico, redução da subluxação e posicionamento correto dos pinos de Steinmann. Nesse caso, a melhora clínica foi atribuída a estabilização da articulação.

Descritores: Instabilidade atlantoaxial, agenesia do processo odontóide, estabilização ventral, pinos transarticulares. 


\section{INTRODUCTION}

Atlantoaxial instability is caused mainly by congenital malformations of the odontoid process of the axis or traumatism and causes cervical spinal cord compression $[9,14,18]$. The congenital form has been observed usually in young dogs of the smaller breeds. Clinical signs exhibited by affected dogs range from pain in the cervical region to tetraplegia. Definitive diagnosis of atlantoaxial instability can usually be made using survey radiographs $[5,21]$. Normally the instability is demonstrated on lateral radiograph and is characterized by increased space between the dorsal spine of the axis and the dorsal arch of the atlas [8,20]. However, necropsy in a dog with signs of superior motor neuron in the four limbs revealed dysplasia of the odontoid process as cause of compression of the spinal cord, in presence of intact atlantoaxial dorsal ligament [17].

Atlantoaxial instability can be treated conservatively or surgically [4]. This paper describes a case of atlantoaxial instability secondary to agenesis of the odontoid process of the axis without evidence of rupture of the dorsal atlantoaxial ligament in a dog treated sucessfully. To the author's knowledge these has not been reported.

\section{CASE REPORT}

A nine-month-old male Lhasa Apso weighing $8.5 \mathrm{~kg}$ was referred to the Neurology Section of the Hospital de Clínicas Veterinárias (Veterinary Medical Teaching Hospital), Universidade Federal do Rio Grande do Sul (UFRGS), Porto Alegre/Brazil. Neurological examination evidenced normal mental state, normal head posture and coordination and normal evaluation of cranial nerves; hyperesthesia to palpation of cranial cervical area; non-ambulatory tetraparesia with increased reflexes in thoracic limbs (flexor) and posterior limbs (flexor and patelar).

Ventrodorsal and lateral survey radiographs were obtained. Ventrodorsal view revealed absence of odontoid process of the axis (Figure 1A). Lateral view showed no changes in the dorsal atlantoaxial space (Figure 1B). The diagnosis of atlantoaxial instability secondary to absence of the odontoid process of the axis was based upon clinical signs and ventrodorsal radiograph. Authors decided to make the surgical stabilization of the atlantoaxial joint. Prophylatic antibiotics (ampicillin ${ }^{1}$ at $22 \mathrm{mg} / \mathrm{kg}$ i.v.) was administered. The dog was premedicated with tramadol ${ }^{2}(2 \mathrm{mg} / \mathrm{kg}$ i.m.). Anaesthesia was induced with propofol ${ }^{3}(2 \mathrm{mg} / \mathrm{kg}$ i.v. $)$ and fentanil ${ }^{4}(5$ $u \mathrm{~g} / \mathrm{Kg}$ i.v.). The anaesthesia was maintained with isoflurane $^{5}$ vapuorized in oxygen, delivered via a circle rebreathing system. Ringer lactate ${ }^{6}(10 \mathrm{~mL} / \mathrm{kg} / \mathrm{h}$ i.v. $)$ was administered throughout the surgical procedure.

The dog was placed in dorsal recumbency, with the neck in extension and the cervical area and proximal humerus were prepared for aseptic surgery. A ventral midline skin incision was made from the level of the larynx to the midcervical area. The sternohyoideus muscles were separed along their midline and the esophagus and trachea were retracted to the left. The sternothyroid muscle was incised close to the larynx. The tendons of the longus colli muscle was elevated from the atlas. The joint space was opened using a scalpel blade. The articular cartilage was removed. The atlantoaxial joint was aligned and stabilized with two $1.5 \mathrm{~mm}$ Steinman pins. Pins were driven from the center of the axis directed towards the alar notch of the atlas. They then were cut so that $1 \mathrm{~cm}$ of pin was left protruding from ventral aspect of the axis body.

Methylmetacrylate resin ${ }^{7}$ was prepared and molded around the pins. During the polymerization the region was irrigated with cold sterile saline solution. Cancellous bone collected from the proximal humerous and placed in and around the joint space. Longus colli muscle was sutured using a simple continuous suture pattern with 3-0 polyglactin ${ }^{8}$. The subcutaneous tissues were closed in a simple continuous suture pattern with 3-0 polyglactin. The skin was closed with simple interrupted sutures pattern with 4-0 nylon?

Ketoprofen ${ }^{10}$ ( $2 \mathrm{mg} / \mathrm{kg}$ 4-hourly) was administered during three days. Enrofloxacine ${ }^{11}(5 \mathrm{mg} / \mathrm{kg}$ v.o.) was give for ten days following surgery. Tramadol ( $3 \mathrm{mg} / \mathrm{kg}$ i.m.) each $8 \mathrm{~h}$ during two days.

\section{DISCUSSION}

Atlantoaxial instability can be associated with congenital malformations of the odontoid process of the axis or traumatic causes resulting in an unstable articulation $[9,14,18]$. Congenital instability occurs most commonly in small breed dogs less than one year of age [8]. Such an assertion could be proven in this case. However, the atlantoaxial instability has also been seen in older dogs as a result of trauma [15].

Clinical signs vary according to the degree of luxation and they may range from cervical pain, ataxia of the four limbs, tetraparesia and standing incapacity 
$[2,8,21]$. The clinical signs in the present case were consistent with reports in the literature.

In the most cases survey radiograph allows diagnosis of atlantoaxial instability $[4,8]$. The ventrodorsal view is useful for examining the odontoid process of the axis to see if it is absent, small, or fractured [7,20]. In the lateral view the diagnosis can be made if the space between the dorsal spine of the axis and the dorsal arch of the atlas is wider than normal $[2,19]$. An interval of 4-5 $\mathrm{mm}$ between the lamina of $\mathrm{C} 1$ and spinal cord of $\mathrm{C} 2$ confirms the diagnosis of atlantoaxial instability [4]. However, on lateral projection no increase in the space between the dorsal spine of the axis and the dorsal arch of the atlas could be seen. The diagnosis of atlantoaxial instability was based upon clinical signs and ventrodorsal radiograph. In the radiological examination in ventrodorsal view it was observed absence of the odontoid process which, once associated to clinical signs, allows the diagnosis of atlantoaxial instability. This is consistent with previous report that atlantoaxial instability can be present in a patient with intact dorsal atlantoaxial ligament [17].

In the lateral projection no increase in the space between the dorsal spine of the axis and the dorsal arch of the atlas evidences doesn't exclude the possibility of atlantoaxial instability. Occasionally it is impossible to reach radiographic confirmation and treatment should be instituted based in the strong suspects, however, without confirmation. In these cases, all the other differential diagnoses should be taken carefully into account, because the clinical signs can mimetize the signs of disc disease, discospondylitis, or traumatism [12]. It is not uncommon to make a diagnosis based only in clinical signs, after the discard of all other possibilities [12].

Atlantoaxial instability can be treated conservatively or surgically. Nonsurgical treatment by cage rest, application of a neck brace and use of anti-inflammatory medications has been advocated when neurological involvement is minimal $[4,8]$. Recovery has been reported with conservative management alone, although surgical fixation is preferred to avoid possible recurrence [8]. Surgical procedures are indicated for most patients with congenital lesions. Surgical stabilization of the atlas and of the axis has been proposed as the best therapeutic method [11,21]. Objectives of surgery include reduction of atlantoaxial subluxation, decompression of spinal cord and nervous roots and atlantoaxial joint stabilization [4]. Surgical methods can be divided into dorsal and ventral stabilization procedures [8]. Publi-
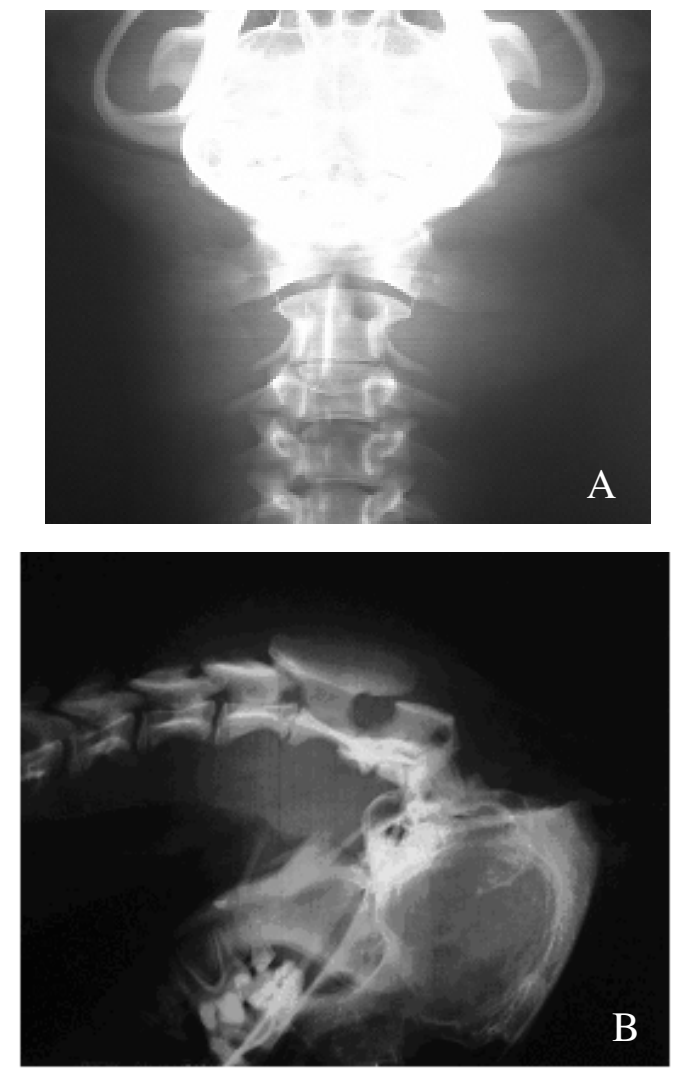

Figures 1A and 1B. Radiograph examination in ventrodorsal (A) e lateral (B) positions (R. Voll, 2003).

shed reports indicate a better outcome using ventral stabilization methods $[8,13]$. The ventral approach permits decompression of spinal cord by allowing alignment and stabilization of the atlantoaxial joint [13]. In this report the choice of surgical method was based on the fact that the instability was caused by congenital alteration which, according to the authors, improvement through nonsurgical treatment, in these specific cases, in general are transitory and deterioration of condition usually happens soon afterwards the return to normal activities [8, 21]. Furthermore, previous reports indicate a better outcome using ventral stabilization methods $[4,8]$.

One week after the surgery, neurological examination revealed ambulatory tetraparesis. Postoperative radiograph confirmed correction of the vertebral subluxation and proper positioning of pins (Figure 2). Six weeks following surgery the dog was with discreet hypermetry of thoracic limbs and the radiograph showed that the Steinmann pins broke (Figure 3). Implant failure either by migration or breakage can occur. If occurs early in the post-operative period, repeat surgery is often required. However, if its occurs later than four weeks, the atlantoaxial joint generally remains well aligned and stable [13]. In the present case, the clinical improvement 
was attributed to the joint stabilization and fibrous tissue formation around of the atlantoaxial joint.

Diagnosis of atlantoaxial instability cannot be definitely excluded due to normality of the lateral radiographic view. Atlantoaxial instability associated to odontoid process agenesis can settle down without the evidence of dorsal atlantoaxial ligament rupture. The identification of neurological deficiency signs with characteristics of injury located in the spinal cord between C1-C5, or else just pain in the cranial cervical area associated with ventrodorsal radiograph evidencing agenesis of the odontoid process, is enough for diagnosis of atlantoaxial instability. Breed and age were important factors for the diagnosis because this condition generally occurs in dogs younger than 1 year of age of the smaller breeds. Adequate stabilization of the atlantoaxial joint appears to have been achieved based
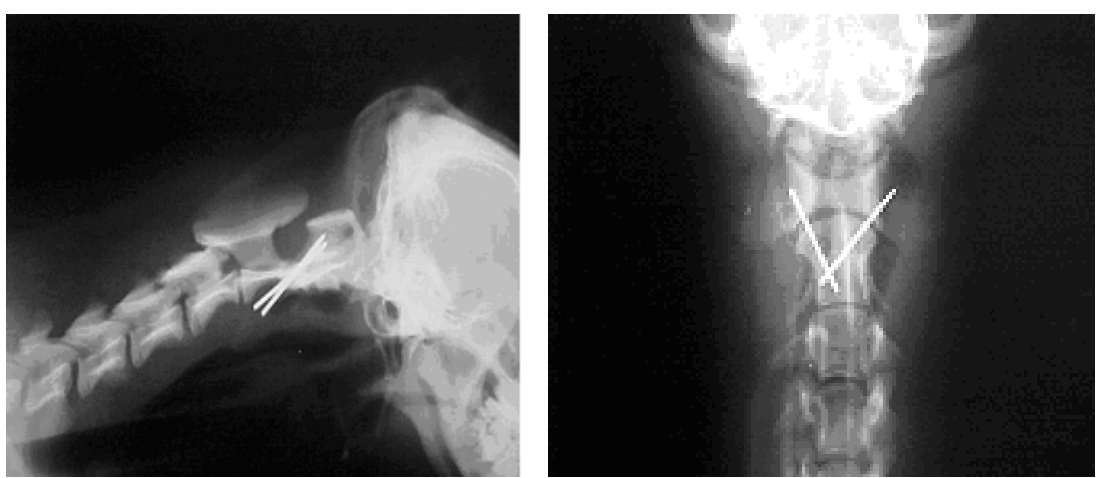

Figure 2. Lateral and ventrodorsal radiograph examination showing the correct positioning of Steinmann pins seven days after the surgery (R. Voll, 2003).
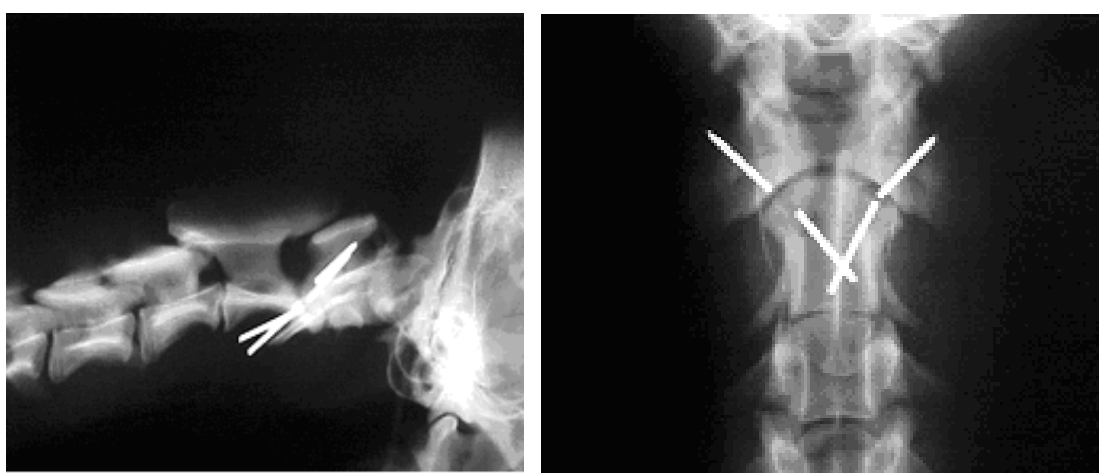

Figure 3. Lateral and ventrodorsal radiograph examination showing breakage of Steinmann pins (R. Voll, 2003). on resolution of clinical signs.

\section{SOURCES AND MANUFACTERS}

${ }^{1}$ Ampicilina sódica: Bristol-Myers, Santo Amaro, SP.

${ }^{2}$ Tramadol, Cristália Produtos Químicos e Farmacêuticos, Itapira, SP.

${ }^{3}$ Diprivan, Abbott Laboratórios do Brasil, São Paulo, SP. ${ }^{4}$ Fentanil: Cristália Produtos Químicos e Farmacêuticos, Itapira, SP.
${ }^{5}$ Forane, Abbott Laboratórios do Brasil, São Paulo, SP. ${ }^{6}$ Cloreto de sódio, potássio e cálcio lactato, Texon Indústria Farmacêutica, Viamão, RS.

${ }^{7}$ Acrílico auto polimerizante Jet: Laboratório Clássico, São Paulo, SP.

${ }^{8}$ Vicryl 3-0: Ethicon, São Paulo, SP.

${ }^{9}$ Mononylon 4-0: Cirumédica, São Paulo, SP.

${ }^{10}$ Ketofen !\%, Rhodia Mérieux Veterinária Ltda., Paulina, SP.

${ }^{11}$ Flotril $50 \mathrm{mg}$, Schering-Plough, Cotia, SP.

\section{REFERENCES}

1 Badkur D.S. \& Arora A. 1999. Trivial injuries, associated congenital anomaly and medicolegal interpretation of death. Medicine Science and the Law. 39 (Suppl 1): 72-75.

2 Chrisman C.L. 1985. Tetraplegia, Tetraparesia, Ataxia dos Quatro Membros e Fraqueza Episódica. In: Neurologia dos Pequenos Animais. São Paulo: Roca, pp.308-309.

3 Denny H.R., Gibbs C. \& Waterman A. 1988. A. Atlantoaxial subluxation in the dog: a review of thirty cases and evaluation of treatment by lag screw fixation. Journal of Small Animal Practice. 29: 37-47.

4 Fossum T.W. 2002. Cirurgia da espinha cervical. In: Cirurgia de Pequenos Animais. São Paulo: Roca, pp.1159-1215.

5 Haid Jr. R.W. 2001. C1-C2 transarticular screw fixation: Technical aspects. Neurosurgery. 49: 71-74.

6 Hicazi A., Acaroglu E., Alanay A., Yazici M. \& Surat A. 2002. Atlantoaxial rotatory fixation-subluxation revisited: A computed tomographic analysis of acute torticollis in pediatric patients. Spine. 27: 2771-2775.

7 Lecouteur R.A. \& Child G. 1997. Afecções da medula espinhal. In: Ettinger S.J. \& Feldman E.C. (Eds). Tratado de Medicina Veterinária Interna. 4.ed. São Paulo: Manole, pp.903-906.

8 McCarthy R.J., Lewis D. \& Hosgood G. 1995. Atlantoaxial Subluxation in dogs. Compendium on Continuing Education Practice Veterinary. 17: 215. 
9 Nelson R.W. \& Couto C.G. 1994. Distúrbios da medula espinhal. In: Nelson R.W. \& Couto C.G. (Eds). Fundamentos de Medicina Veterinária Interna. Rio de Janeiro: Guanabara Koogan, pp.580-583.

10 Oliver J.E. 1996. Traumatismo do sistema nervoso central. In: Lorenz M.D., Cornelius L.M. \& Ferguson D.C. (Eds). Terapêutica Clínica em Pequenos Animais. Rio de Janeiro: Interlivros, pp.280-281.

11 Rochat M.C. \& Shores A. 1998. Fixation of an Atlantoaxial subluxation by use of cannulated screws. Veterinary and Comparative Orthopaedics and Traumatology. 11: 43-46.

12 Shires P.K. 1998. Instabilidade Atlantoaxial. In: Slatter D. (Ed). Manual de Cirurgia de Pequenos Animais. 2.ed. São Paulo: Manole, pp.1261-1269.

13 Sorjonen D.C. \& Shires P.K. 1981. Atlantoaxial instability: A ventral technique for decompression, fixation, and fusion. Veterinary Surgery. 10: 22-29.

14 Swaim S.F. \& Greene C.E. 1975. Odontectomy in a dog. Journal of the American Animal Hospital Association. 11: $663-666$.

15 Thomas W.B., Sorjonen D.C. \& Simpson S.T. 1991. Surgical management of atlantoaxial subluxation in 23 dogs. Veterinary Surgery. 20: 409-412.

16 Todorov A.B., Merden D.F., Borgaonkar D.S. \& French B.N. 1978. Atlantoaxial malformation in a 46 XY, 17q+child. Archives of Neurology. 35: 317-320.

17 Zaki F.A. 1980. Odontoid process dysplasia in a dog. Journal of Small Animal Practice. 21: 227-234.

18 Wagner S.D. 1998. Fraturas e deslocamentos espinhais. In: Sherding R.G. \& Birchard S.J. (Eds). Manual Saunders, Clínica de Pequenos Animais. São Paulo: Roca, pp.1083-1085.

19 Wheeler S.J. \& Sharp N.J.H. 1999. Exame do Paciente. In: Diagnóstico e Tratamento Cirúrgico das Afecções Espinais do Cão e do Gato. São Paulo: Manole, pp.21-30.

20 Wheeler S.J. \& Sharp N.J.H. 1999. Auxílio Diagnóstico. In: Diagnóstico e Tratamento Cirúrgico das Afecções Espinais do Cão e do Gato. São Paulo: Manole, pp.34-56.

21 Wheeler S.J. \& Sharp N.J.H. 1999. Subluxação Atlantoaxial. In: Diagnóstico e Tratamento Cirúrgico das Afecções Espinais do Cão e do Gato. São Paulo: Manole, pp.109-121. 